\title{
O Movimento de Três Passos e o processo de construção de hegemonia
}

\author{
Gabriel Pancera Aver
}

Recebido em maio de 2019 Aceito em outubro de 2019

\section{RESUMO}

Por meio da experiência do primeiro movimento armado contra o regime militar brasileiro, conhecido como Movimento de Três Passos, o presente artigo busca refletir sobre o processo de construção de hegemonia, por meio dos aportes teóricos de Gramsci, reflexionando acerca do agenciamento de coerção e consenso em relação ao referido Movimento. Por meio da análise de fontes históricas primárias, buscase relacionar a narrativa midiática acerca do Movimento com a formação de uma opinião pública específica e, em última instância, a construção de um consenso tácito de aversão ao comunismo, tanto em nível micro, com a experiência de Três Passos, quanto em nível macro, deslocando a referida problemática ao contexto da redemocratização. Sendo assim, o presente trabalho colabora na reflexão acerca do agenciamento de consenso no contexto da ditadura militar, entendido como um processo contínuo e conflituoso, para repensar a redemocratização nacional dentro da chave analítica da construção de hegemonia.

Palavras-chave: Hegemonia; Movimento de Três Passos; Consenso; Ditadura Militar; Coerção.

\begin{abstract}
Through the experience of the first armed movement against the Brazilian military regime, known as the Três Passos Movement, the present article sought to reflect, through Gramsci's theoretical contributions, about the process of hegemony construction, reflecting on the agency of coercion and consensus on that Movement. Through the analysis of primary historical sources, the aim was to relate the media narrative about the Movement with the construction of a tacit consensus of aversion to communism, both at the micro level, with the Três Passos historical experience, and at the macro level, displacing the referred to the context of redemocratization. Thus, the present work contributes to the reflection on consensus construction, understood as a continuous and conflicting process, within the context of the military dictatorship to rethink national redemocratization within the analytical key of hegemony construction process.
\end{abstract}

Keywords: Hegemony; Três Passos Movement; Consensus; Military Dictatorship; Coercion.

${ }^{1}$ Mestrando do Programa de Pós-Graduação em sociologia da Universidade Estadual de Londrina (PPGSOC/UEL) na linha de pesquisa Desigualdades, Cidadania e Cultura. Email: aver_gabriel@hotmail.com. 


\section{Introdução}

Após a consolidação e ascensão do regime militar em 1964, o exílio foi a alternativa que muitas e muitos cidadãos e cidadãs brasileiras/os, ameaçadas/os pelas arbitrariedades do regime militar, encontraram para proteger e garantir a integridade da própria vida. O processo de cruzar a fronteira tornou-se, portanto, um fator central no agenciamento de movimentos de oposição ao regime militar, os quais visavam a retomada do poder político brasileiro.

No contexto dos exílios e, neste caso em específico, na cidade de Montevidéu, no Uruguai, planejou-se e organizou-se o primeiro movimento armado contrário à ditadura militar brasileira, no ano de 1965. O referido movimento ficou conhecido como Movimento de Três Passos, tendo em vista que os insurgentes começaram efetiva e publicamente as suas ações no município de Três Passos, no oeste do Rio Grande do Sul.

Desse modo, por meio desta experiência histórica de oposição armada, busca-se retomar as discussões presentes no pensamento de Gramsci sobre o processo de construção de hegemonia e o agenciamento de consenso e coerção, passando, portanto, pelos conceitos de sociedade civil e sociedade política, com o intuito de pensar: Qual a atuação dos aparelhos privados de hegemonia na construção de consenso e coerção?

Ora, na tentativa de discorrer sobre a presente temática, devem-se retomar questões centrais do pensamento de Gramsci que encontram, por vezes, pela própria complexidade de forma dos escritos deixados pelo autor, divergências entre diversos/as autores/as que se debruçam sobre os aportes do filósofo e político italiano. Assim, como exemplo, é possível citar a complexa unidade entre coerção e consenso, o processo de formação de hegemonia e as relações entre sociedade política e sociedade civil. Perpassando essas temáticas, a presente pesquisa busca colaborar na compreensão e na problematização de alguns conceitos centrais dentro do pensamento gramsciano à luz dos conceitos teóricos do próprio autor, assim como por meio dos aportes de comentadores, dentre os quais destacam-se Rey (2010), Bianchi (2008) e Roseberry (2002). 
Nesse âmbito, a partir influência da mídia na construção de uma narrativa específica acerca do referido Movimento, o presente trabalho busca reflexionar sobre a análise e compreensão da sociedade civil e da sociedade política como duas esferas estáticas, problematizando a existência ou não de fronteiras concretas entre ambas. Busca-se evidenciar que o discurso midiático em relação ao Movimento logrou formar uma opinião pública específica em relação à insurgência e aos insurgentes que, em última instância, colaborou na legitimação de práticas sociais e políticas de Estado repressivas.

De mesmo modo, busca-se articular a relação entre opinião pública e construção de consenso, com o objetivo de propor a reflexão acerca da construção de hegemonia durante o período da ditadura militar brasileira, associando consenso e coerção. Dessa maneira, ao entender hegemonia como um processo de disputa contínua, o presente artigo visa discorrer e problematizar o consenso em relação a redemocratização, buscando relacionar a experiência micro do Movimento de Três Passos, com o contexto histórico e político macro da redemocratização nacional.

Contudo, antes de nos aprofundarmos nos debates teóricos propostos, devemse retomar algumas considerações historiográficas sobre o referido Movimento insurgente, a fim de localizar histórica e geograficamente o/a leitor/a.

\section{Considerações históricas acerca do movimento de três passos}

Há uma expressiva quantidade de produções acadêmicas que buscam revisitar, a partir de distintas perspectivas e recortes, o Movimento de Três Passos. Para lograrmos contextualizar minimamente o/a leitor (a), retomaremos a dissertação de mestrado de Cademartori (1993) e os relatos de Palmar (2012).

Nessa perspectiva, Cademartori (1993) destaca que, entre as exiladas e os exilados no Uruguai, ainda que houvesse uma disputa entre duas tendências de oposição, armada ou não, preponderavam as/os adeptos à "resistência” armada. Afirma ainda que "[...] a ideia que prevalecia era a de que qualquer insurgência no sentido de retomar o poder perdido com o golpe de 31 de março seria facilmente vitoriosa" (CADEMARTORI, 1993, p. 132). As intenções do movimento de exilados e exiladas era de 
aproveitar as bases que o governo Goulart ainda mantinha no Brasil para, no prazo máximo de um ano, retomar o poder político a fim de que o regime militar não conseguisse se consolidar. O Movimento de Três Passos começa a ser planejado neste contexto de disputa interna do próprio conjunto de exilados/as em Montevideo.

Dentre os $^{2}$ que planejaram e executaram a operação Três Passos, destacam-se Alberi Vieira dos Santos e Jefferson Cardim de Alencar Osório. Ambos foram militares expulsos da corporação após a consolidação do regime militar. Os dois tiveram uma participação ativa e determinante nas ações do movimento, as quais podem ser detalhadamente encontradas no diário $^{3}$ de Jefferson Cardim e na dissertação de Cademartori (1993).

O grupo de aproximadamente treze insurgentes chegou ao município de Três Passos na noite do dia 25 de março de 1965. Nessa noite, “[...] o grupo deixou a cidade sem comunicação telefônica, pois cortaram os fios da rede, e posteriormente tomaram o presídio e o destacamento da brigada militar, de onde levaram armas, munições e fardas" (PALMAR, 2012, p. 289). Narra-se que:

\begin{abstract}
Entraram no alojamento e mandaram os homens se levantarem e quando viram o coronel fardado se levantaram assustados, todos de cuecas. Jefferson e seus comandos apanharam todo o armamento existente no destacamento e mais fardamento e munições, atravessaram a rua e entraram no presídio. O guarda que guarnecia a portaria se assustou e correu para o fundo, que não tinha saída. O outro guarda viu e também fugiu (PALMAR, 2012, p. 290).
\end{abstract}

Nesse viés, partiram do presídio em direção à delegacia, contudo, como destaca Palmar (2012), encontraram o delegado no caminho e esse declarou apoio ao Movimento e, sendo assim, os insurgentes seguiram em direção à rádio municipal de Três Passos. Chegando à rádio, obrigaram “[...] sob a mira de uma metralhadora, os proprietários a

${ }^{2}$ Nesse momento, não se utiliza o pronome “as", tendo em vista que em nenhum documento histórico lido e analisado pelo autor foram encontrados nomes de mulheres que integraram ou planejaram o movimento, nem mesmo nos trabalhos acadêmicos e nas sentenças deferidas aos insurgentes após suas capturas. Destaca-se, entretanto, a necessidade do desenvolvimento de pesquisas com este recorte específico dentro do contexto do Movimento de Três Passos.

3 Disponível em: <https://www.plural.jor.br/documentosrevelados/repressao/finalmenterevelado-o-diario-do-coronel-jefferson-cardin-lider-da-guerrilha-dos-dentes-de-ouro/>. Acessado em 9 de agosto de 2019 . 
colocar a emissora no ar para ler um manifesto contra a ditadura militar que defendia as reformas de base e conclamavam o povo para a revolução” (PALMAR, 2012, p. 290).

Tendo sido lido o manifesto, os insurgentes partiram de Três Passos em direção ao município de Tenente Portela (RS) com o objetivo de tomar a guarnição militar do município. Em Portela, “[...] o sargento que estava sozinho [no destacamento] fugiu, pulando uma janela e saindo disparado pela rua [...] Osório ocupou a mesa do sargento, enquanto o grupo quebrava a estação de rádio e cortava o telefone" (PALMAR, 2012, p. 291). Ademais, em Portela, usaram a rádio para ouvir as notícias referentes às suas ações, isto é, para acompanhar a transmissão do desenrolar dos acontecimentos via rádio.

Posteriormente, no seu descolamento ao longo da região oeste dos estados de Santa Catarina e Paraná, a Força Aérea brasileira localizou o grupo e, nas proximidades do município de Capitão Leônidas Marques-PR, o cercou. Durante o cerco, militares e insurgentes entraram em conflito direto, durante o qual os insurgentes se dividiram em ambos os lados da estrada e, com a chegada da patrulha militar, o Exército e o grupo entraram em confronto direto, tendo em vista que o tenente da patrulha ordenou que os militares abrissem fogo contra o grupo de insurgentes.

No confronto, o sargento militar Carlos Argemiro de Camargo foi atingido por um dos disparos e faleceu. Deste modo, segundo Palmar (2012), foi acertada uma trégua para que o Exército pudesse recolher o corpo do Sargento atingido. No momento em que o confronto cessou, o grupo escondeu suas armas na mata e se dispersou com o objetivo de fugir da região.

Aos poucos, os insurgentes foram capturados pelo Exército e levados à Foz do Iguaçu, onde foram torturados. Segundo relato publicado no Coojornal em 1978 e disponível em Gaspari4 (2002), a chegada dos insurgentes de Três Passos em Foz do Iguaçu foi repleta de atos de violência psicológica e física:

Cardim pagou sua conta na moeda dos vencedores. Antes de qualquer interrogatório, um capitão jogou-o no chão e, depois de chutá-lo, ordenou que a tropa "cuspisse na cara desse filha da puta, comunista, assassino". Foi espancado e crucificado nas grades de sua cela. Torturaram-no em três quartéis diferentes. Em um deles teve demência e foi submetido a tratamento médico (COOJORNAL, 1978 Apud: GASPARI, 2002, p. 443).

4 Ver: Gaspari, 2002. p. 443. 
Antes de serem apresentadas as demais punições e sentenças aferidas aos insurgentes, devem-se retomar algumas questões referentes à atuação da mídia e, de mesmo modo, as consequências da referida atuação.

\subsection{A mídia, a elucidação dos fatos e as práticas sociais}

A pesquisa ${ }^{5}$ metodológica aqui proposta parte da análise de documentos como técnica de coleta de dados e da análise do discurso como técnica analítica dos dados coletados, a partir dos aportes de Flick (2009). Nesse sentido, para contemplar os objetivos propostos, elencaram-se documentos referentes ao discurso produzido pela mídia, pelo próprio Movimento e pela população. Os documentos referentes a categoria "mídia" foram selecionados de acordo com a circulação ${ }^{6}$ nacional e regional dos periódicos. Desse modo, foram selecionadas as publicações referentes ao Movimento de Três Passos no Jornal Folha de São Paulo e no Jornal Correio do Povo, sendo um dos maiores jornais em circulação a nível nacional e regional, respectivamente. Na categoria "população" foram selecionadas fontes primárias que se constituem fundamentalmente como relatos de pessoas que vivenciaram o Movimento sem estarem diretamente a ele vinculadas e que tampouco possuíam vínculo direto com a mídia ou o Exército. Nesse sentido, resgatam-se o relato do radialista de Três Passos e um registro visual de camponeses. Por fim, para a categoria referente ao discurso produzido pelo próprio Movimento, resgata-se o diário de Jefferson Cardim.

Nessa perspectiva, sabendo que, como indicado na introdução do presente trabalho, parte-se de uma interpretação gramsciana da realidade social, os presentes documentos foram selecionados a fim de buscar compreender a mídia, entendida como

${ }^{5} \mathrm{~A}$ análise aqui apresentada constitui-se como um recorte da pesquisa desenvolvida pelo autor. Sendo assim, os próprios limites de formatação do artigo não possibilitam a apresentação total dos dados informados. Busca-se aqui sintetizar de modo que o leitor/a possa compreender minimamente a coleta e a correlação dos dados. A pesquisa em sua íntegra pode ser consultada em: <http://dspace.unila.edu.br/123456789/5083>. Acessado em 15 de novembro de 2019.

${ }^{6} \mathrm{O}$ Jornal Folha de São Paulo publicou a primeira manchete referente ao Movimento insurgente de Três Passos no dia 26 de março de 1965 e seguiu acompanhando e veiculando diariamente notícias referentes ao Movimento até o dia 29 de março. De mesmo modo, o Jornal Correio do Povo teve veiculação diária de informações e narrativas referentes ao Movimento entre os dias 27 e 29 de março de 1965. 
aparelho privado de hegemonia e as suas influências na articulação de consenso, bem como a maneira como o consenso opera no âmbito da coerção. Dessa maneira, a triangulação proposta nos permite vislumbrar a disputa discursiva, tendo-a como reflexo da discuta política entre a mídia e o Movimento e, de mesmo modo, como essa disputa se reflete nas ações práticas da população - ou de um extrato dela -. Assim, a análise metodológica proposta objetiva possibilitar a problematização do agenciamento de coerção e consenso dentro do contexto de disputa política e discursiva em relação ao Movimento de Três Passos.

Tabela 1: Síntese Ilustrativa dos Documentos Coletados

\begin{tabular}{|c|c|c|}
\hline Documentos da mídia & Documentos da população & $\begin{array}{c}\text { Documentos do } \\
\text { Movimento }\end{array}$ \\
\hline $\begin{array}{c}\text { Correio do Povo: } \\
\text { Sequência de reportagens }\end{array}$ & $\begin{array}{c}\text { A noite em Três Passos: } \\
\text { Relato do radialista }\end{array}$ & $\begin{array}{c}\text { Diário de Jefferson Cardim } \\
\text { de Alencar Osório }\end{array}$ \\
\hline Folha de São Paulo: & Registro fotográfico: & \\
Sequência de reportagens & Acervo documentos & \\
& revelados & \\
\hline
\end{tabular}

Fonte: Autoria própria, 2019.

Em relação aos documentos referentes ao discurso da mídia elencaram-se três categorias $^{8}$ analíticas oriundas de uma análise que visava compreender a construção histórico-discursiva sobre o objeto de estudo do presente trabalho. A primeira delas está relacionada à inconsistência do Movimento. Tanto as notas do Exército, quanto os trechos editados pelo próprio corpo editorial dos jornais, apontavam a atuação em âmbito restrito, alegando que, devido à insignificância numérica de insurgentes e a falta

${ }^{7} \mathrm{O}$ diário de Osório não está publicado integralmente. As páginas publicadas são de acesso livre e estão disponíveis em: <https://www.documentosrevelados.com.br/repressao/finalmente-revelado-odiario-do-coronel-jefferson-cardin-lider-da-guerrilha-dos-dentes-de-ouro/>. Acessado: 21 de Novembro de 2019 .

${ }^{8}$ A elaboração das referidas categorias deu-se a partir da análise e correlação das reportagens utilizadas, visando mapear a formação do discurso ao longo dos 4 dias em que a mídia veiculou reportagens e notas oficiais do Exército sobre o Movimento. A visualização pormenorizada da construção das categorias pode ser consultada na íntegra da pesquisa, já disponibilizada anteriormente em nota de rodapé. 
de apoio na sociedade, o Movimento seria rapidamente resoluto. Ainda, afirmavam que o mesmo estava concentrado na figura de Jefferson Cardim, construindo uma narrativa baseada na personalização das ações dos insurgentes.

A segunda categoria elencada é a caracterização do Movimento, ou seja, os adjetivos empregados pela mídia e pelo Exército ${ }^{9}$, via nota oficial, para caracterizar os insurgentes e suas ações, dentre os quais se destacam as expressões "baderneiros", "mercenários", "guerrilheiros" e "desordeiros". Ora, se os insurgentes representavam a desordem e a baderna, pode-se afirmar que, na visão e na narrativa dos jornais, há uma ordem e uma “organização” já instituída à qual os insurgentes buscam confrontar?

Há, portanto, uma terceira categoria, a saber, a existência narrativa de uma ordem instituída. Essa autoridade, representada pela ordem do próprio Estado brasileiro, não se propõe apenas à manutenção de um regime ou de uma forma de governo específica. A existência de uma ordem perpassa, na narrativa das reportagens analisadas, a condição de checagem e elucidação dos fatos. Ou seja, para além de concentrar em si o papel da ordem, o Estado brasileiro assume a posição de agente de elucidação dos fatos, nos quais, segundo as notas oficiais do Exército, a população deveria confiar. A fonte de informações confiáveis que se opunha em veracidade aos “boatos alarmistas" e, do mesmo modo, à fonte que “elucidará os fatos”, está concentrada nas mãos do Exército que, neste momento, era o poder executivo nacional. Por conseguinte, percebe-se o controle do Estado na transmissão da informação e a ação dos jornais, pois por intermédio da construção das reportagens, há a reprodução de uma narrativa específica acerca do movimento de Três Passos.

Logo, atrelando e correlacionado os três elementos anteriores, chega-se à construção histórica e política do Movimento presente no discurso midiático. Buscouse caracterizar politicamente o Movimento frente à sociedade a partir da personalização da figura de Osório, desprovido de apoio popular, atuando em ambiente restrito, desobedecendo a ordem estabelecida e, em última instância, ameaçando a segurança da

9 Neste momento mídia e Exército estão diretamente correlacionados tendo em vista o alto índice de trechos com citação direta às notas oficiais do Exército no corpo do texto das reportagens analisadas. 
população que ali residia. O Movimento teve a sua imagem publicamente construída e, em contrapartida, encontra-se afônico frente ao discurso da mídia.

O diário de Osório contradiz fortemente o discurso jornalístico de que o Movimento não possuía apoio popular, tendo em vista que evidencia e comprova o apoio de diversos partidos e organizações da sociedade civil, bem como de pequenos camponeses, em todo o deslocamento, desde o Uruguai até Três Passos. Essa constatação contraria também a perspectiva de personalização do Movimento e de sua incapacidade de atuar politicamente de forma expressiva. Além disso, resta-nos apontar como algumas ações da população podem estar correlacionadas com a identificação dos insurgentes como baderneiros, mercenários e ameaçadores da segurança local.

Os relatos publicados no Coojornal ${ }^{10}$ (1978), afirmam que, na cidade de Foz do Iguaçu, onde Alberi e Osório chegaram para serem presos, formou-se um corredor de civis que escarravam nos insurgentes enquanto esses eram levados para dentro do Batalhão. A "comitiva do escarro", como foi denominada pelo Coojornal, formou-se a partir de ordens de um capitão do Exército.

A reação da população pode ser percebida a partir do relato do radialista, que teve sua rádio ocupada pelo Movimento na noite em que esses chegaram em Três Passos. No discurso do radialista há dois elementos centrais. O primeiro faz referência à condição da população, isto é, a sensação que, segundo ele, tomou conta da cidade após as ações do movimento, assim como as medidas tomadas por parte da população. $\mathrm{O}$ segundo elemento faz referência à própria ação do movimento.

Nesse âmbito, segundo o radialista, naquela noite estavam todos apavorados. Alguns fugiram da cidade, como, por exemplo, o prefeito de Três Passos, Alcides Braun. Outros foram ao banco e recolheram suas economias, levando-as para casa. Em suma, o radialista descreve uma sensação de medo, atrelado à incerteza em relação a real magnitude das consequências da ação do movimento. $\mathrm{O}$ medo, atrelado à incerteza, fica

\footnotetext{
${ }^{10}$ Os relatos do Coojornal, pela própria característica jornalística do texto, isto é, contrário à ditadura e ligado aos movimentos de oposição ao regime militar, não se enquadram em nenhuma das três categorias propostas à análise. Contudo, são utilizados como material historiográfico complementar, no intuito de contextualizar a chegada dos insurgentes à Foz do Iguaçu. A escolha de retomar os relatos do Coojornal, apesar de não se enquadrarem rigidamente nas categorias metodológicas propostas, possibilitam uma compreensão de um contexto específico que, por outras fontes históricas, ficaria velado. Os referidos relatos podem ser consultados em: COOJORNAL, 1978 Apud: GASPARI, 2002, p. 443.
} 
evidente quando se relata que alguns, ainda que quisessem fugir, preferiram ficar em casa, tendo em vista que dizia-se que o movimento já havia tomado as cidades vizinhas, tal como no trecho no qual o radialista descreve que a cidade passou a madrugada em claro, atenta a possíveis novas movimentações.

Narra-se, ainda, que o prefeito da cidade conseguiu ir até Tiradentes (RS) e lá permaneceu durante toda a noite, retornando a Três Passos apenas na seguinte manhã. Durante esse período, o radialista descreve:

\footnotetext{
“(...) outros fugindo, como foi o prefeito Alcides Braun, que fugiu até Tiradentes e só apareceu no outro dia às 11 horas da manhã, quando o Dr. Goelzer e eu já tínhamos ido na prefeitura, o Goelzer meio que assumiu, já que não tinha ninguém" (DOCUMENTOS REVELADOS, 2015).
}

Desse modo, percebe-se que, segundo a narrativa do radialista, as ações do movimento causaram relativa desordem na ordem social e política na cidade, tendo em vista a fuga do prefeito, causando certa "vacuidade" do maior cargo do poder executivo no município por diversas horas. Antes de passarmos ao segundo elemento, deve-se destacar quem são as/os agentes que aparecem na narrativa do radialista, ainda que ele use as expressões "todo mundo estava apavorado" e "ninguém tinha coragem de sair da cidade", dando a impressão de que o seu relato engloba a totalidade da população de Três Passos. O primeiro agente do discurso é o próprio radialista, tendo em vista que, partindo da concepção do discurso aqui utilizada, as representações do próprio radialista estão impressas no seu discurso, condicionadas pelo contexto no qual o discurso foi emitido. Esse é um elemento fundamental para analisarmos o discurso supracitado, tendo em vista que os donos das rádios eram pessoas com relevância social pela própria centralidade da rádio como fonte de emissão de informação. Além disso, deve-se levar em consideração que o referido radialista teve seu negócio invadido e foi forçado a ler um manifesto escrito pelo movimento.

As/os segundos agentes que aparecem no discurso são aqueles que foram aos bancos recolher dinheiro a fim de esconder suas economias em casa. Ora, ainda que seja uma passagem sutil e relativamente vaga, há que se considerar a realidade social de uma pequena municipalidade do interior do Rio Grande do Sul no ano de 1965. Aquelas e aqueles que tinham condições de ter economias guardadas em um banco, nesse período 
e nesse contexto social e geográfico, não podem ser enquadrados como "todo mundo". Ainda que a informação no discurso do radialista seja vaga e generalizada, sabe-se que as/os segundos agentes que aparecem no discurso eram sujeitos financeiramente abonados.

Os terceiros agentes que aparecem no discurso são o Dr. Goelzer e o prefeito. O Dr. Egon Julio Goelzer era advogado na cidade de Três Passos e estava ligado à política municipal, visto que, anos depois, chegou a ser eleito prefeito do município, como é possível evidenciar a partir de documentos ${ }^{11}$ da câmara municipal de Três Passos. Portanto, podemos caracterizar os terceiros agentes mencionados no discurso do radialista como sujeitos diretamente envolvidos com a política municipal.

Dessa forma, identificar quem são os sujeitos impressos no discurso analisado é importante para não cairmos na generalização discursiva do emissor do discurso. Nesse sentido, não temos um "todo mundo" apavorado e com medo de fugir de Três Passos, mas sim a classe política, aquelas e aqueles abonados que tinham condições de manter economias aplicadas no banco e o radialista. A identificação dos agentes do discurso nos permite ainda vislumbrar e identificar a forma como o radialista aponta a interpretação da ação dos insurgentes, utilizando amplamente de expressões como "tomaram" e “cercaram”, dando um suporte a narrativa de medo generalizado.

Outrossim, outro documento que permite vislumbrar a reação da população é a imagem (ver figura 1) de camponeses auxiliando os militares nas buscas pelos insurgentes, após o conflito direto entre o Movimento e o Exército, nas proximidades de Capitão L. Marques, é possível perceber a constituição e legitimação de práticas sociais específicas em relação ao Movimento de Três Passos. A cooperação com o Exército reforça não somente a ideia de que o Movimento falhou na tentativa de lograr apoio popular expressivo por meio da leitura do manifesto de convocação na rádio, mas também evidencia a ideia de que a caracterização dos insurgentes enquanto inimigos, os quais deveriam ser neutralizados, legitimou-se socialmente.

${ }^{11}$ A partir de projetos de leis municipais aprovados e sancionados na câmara municipal de Três Passos, é possível evidenciar que o referido Dr. Goelzer foi prefeito de Três Passos. Cita-se, como exemplo, a lei № 2283/1973, disponível em: <https://leismunicipais.com.br/a1/rs/t/tres-passos/leiordinaria/1973/223/2238/lei-ordinaria-n-2238-1973-autoriza-o-executivo-a-adquirir-tres-3-caminhoessendo-um-1-a-gasolina-e-dois-2-a-oleo-cru>. Acessado em 17 de novembro de 2019. 


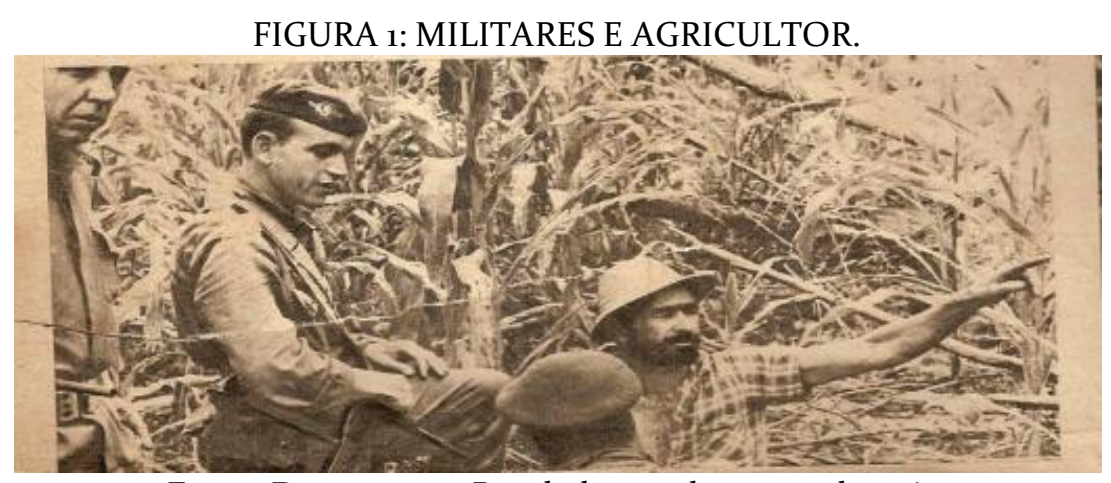

Fonte: Documentos Revelados, 10 de março de 1965.

Tendo sido apresentados os dados extraídos dos documentos coletados, passase ao resgate dos aportes teóricos de Gramsci, que orientam a análise aqui proposta, a fim de, posteriormente, relacionar os resultados oriundos da triangulação dos documentos com a teoria proposta pelo filósofo e político italiano.

Entre o consenso e a coerção: aportes teóricos de Gramsci

As concepções teóricas de Gramsci colaboram para a compreensão do papel da mídia e a construção de consenso em relação ao Movimento. Contudo, antes de conceber a mídia como um aparelho privado de hegemonia, devem-se resgatar alguns conceitos que fundamentam a interpretação proposta.

Nesse contexto, Gramsci introduz o conceito de Estado integral, isto é, compreende o Estado como "[...] todas as forças intelectuais e morais necessárias e suficientes para organizar uma sociedade completa e perfeita” (GRAMSCI, Q 6, § 10, p. 691.). Ou seja, "busca-se escapar de uma concepção que reduziria o Estado ao aparelho coercitivo" (BIANCHI, 20o8, p. 177). Portanto, Gramsci concebe o Estado como: "Estado = sociedade política + sociedade civil, ou seja, hegemonia encouraçada de coerção" (GRAMSCI, Q 6, § 88, p. 763-764) e, posteriormente, no mesmo caderno, como: "Estado (no sentido integral: ditadura + hegemonia) ” (GRAMSCI, Q 6, § 155, p. 810-811). Expande-se, portanto, no pensamento de Gramsci, a concepção de Estado para além da característica coercitiva dos aparelhos estatais, teoricamente alocados na sociedade política. 
Bianchi (2008) traz uma síntese do conceito de sociedade política que colabora para a compreensão do debate: "trata-se do Estado no sentido restrito, ou seja, o aparelho governamental encarregado da administração direta e do exercício legal da coerção" (BIANCHI, 2008, p.178). Contudo, o que se busca aqui destacar é que, ainda que Gramsci não perca a perspectiva da política como coercitiva, não reduz ela a coerção e, para isso, introduz o conceito de sociedade civil para a compreensão do Estado.

\footnotetext{
“(...) pode-se por enquanto fixar dois grandes "planos" superestruturais: o que pode ser chamado de "sociedade civil" (isto é, o conjunto de organizações chamados comumente de "privados") e o da "sociedade política" ou Estado, que correspondem à função de "hegemonia" que o grupo dominante exerce em toda a sociedade e àquela de "domínio direto" ou de comando, que se expressa no Estado e no governo "jurídico" (GRAMSCI, p. 1518 apud ANGELI, 2011, p. 128).
}

Dessa maneira, pode-se entender sociedade civil como organizações privadas (não ligadas à sociedade política) e, consequentemente, não pertencentes à parte jurídica e burocrática do Estado. Segundo Bianchi (2008), o conceito de sociedade civil pode ser percebido de duas maneiras. A primeira, "como forma de exercício e afirmação da supremacia de uma classe sobre o conjunto da sociedade" (BIANCHI, 20o8, p. 182), e a segunda como "a capacidade de iniciativa econômica que o Estado possui no capitalismo contemporâneo" (BIANCHI, 2008, p. 182). Contudo, para além do debate ${ }^{12}$ gerado a partir dessa dupla interpretação do conceito de sociedade civil, o que interessa aos objetivos desse trabalho é compreender que a sociedade civil "mantém uma relação de unidade-distinção com a sociedade política” (BIANCHI, 2008, p. 183) no que diz respeito ao processo de construção de hegemonia.

Sendo assim, a ampliação do conceito de Estado (REY, 2010) está relacionada a sua característica de articular consenso e coerção como modo de legitimar sua dominação. Entretanto, para além de pensar apenas a questão da coerção como manutenção do poder do Estado, Gramsci postula o conceito de aparelhos privados de hegemonia, ou seja, as diversas esferas da sociedade civil, como forma de, para além da coerção, gerar consenso em relação à hegemonia do Estado. Nesse sentido, por meio dos aparelhos privados de hegemonia, a classe dirigente impõe sua visão de mundo aos

\footnotetext{
${ }^{12}$ Sobre a dupla interpretação do conceito de sociedade civil, ver: BIANCHI, 2008, p. 173-185.
} 
demais, uma vez que "a difusão de certos valores está determinada pelas relações de compromisso da classe dirigente com outras forças sociais, expressas no Estado” (REY, 2010, p. 17). Sendo assim, a hegemonia do Estado é fundamentalmente baseada na unidade e articulação entre coerção e consenso.

Deve-se compreender ainda a unidade entre coerção e consenso como um processo de construção de hegemonia, isto é, há a necessidade de despir-se da compreensão da hegemonia como "um processo de dominação e luta problemático, disputado e política, e não como uma forma ideológica terminada e monolítica” (ROSEBERRY, 1994, p. 219). Afirma-se, diante disso, à luz de Roseberry (1994), que a hegemonia não é uma ideologia compartilhada, "mas um marco comum material e significativo para viver através das ordens sociais caracterizadas pela dominação" (ROSEBERRY, 1994, p. 220).

Por fim, à luz do resgate teórico desenvolvido, indaga-se: Qual a atuação dos aparelhos privados de hegemonia na construção e articulação de consenso e coerção no contexto de Três Passos? ${ }^{13}$

\section{A mídia e os limites entre a coerção e o consenso}

A partir do pensamento de Gramsci é possível alocar a mídia, enquanto aparelho privado de hegemonia, dentro da sociedade civil, isto é, como uma esfera da sociedade civil que busca agenciar consenso. Contudo, a distinção entre sociedade civil e sociedade política, por vezes, gera análises bidimensionais, ou seja, atrela-se a sociedade política unicamente à esfera da coerção e a sociedade civil unicamente ao âmbito de produção de consenso. Contudo, como afirma Bianchi (2008), deve-se compreender que a sociedade civil “[...] mantém uma relação de unidade-distinção com a sociedade política” (BIANCHI, 2008, p. 183). Nesse viés, ainda que possam ser agenciadas teoricamente como esferas sociais distintas, no pensamento gramsciano não são duas dimensões

${ }^{13} \mathrm{Na}$ presente pesquisa analisa-se o papel da mídia enquanto aparelho privado de hegemonia. Contudo, sabe-se que não há como compreender a totalidade do processo de construção de hegemonia apenas analisando uma esfera da sociedade civil. Sendo assim, compreende-se a necessidade de seguir pesquisando sobre a influência de outras organizações da sociedade civil na articulação de consenso e coerção em relação ao Movimento de Três Passos. 
isoladas e estáticas, são interdependentes e associam mutuamente a coerção e o consenso, objetivando o agenciamento de hegemonia.

Percebe-se, a partir da análise das reportagens, que se buscou construir uma narrativa específica acerca do Movimento, a qual foi amplamente difundida nos meios de comunicação, enquanto o Movimento encontrava-se afônico. Entretanto, busca-se aqui problematizar a atuação da mídia ${ }^{14}$ indagando: Em que medida a construção de uma narrativa específica acerca do Movimento operou na dimensão da coerção?

Ora, a narrativa produzida pela mídia logrou gerar, em uma parcela da população, uma visão específica acerca do Movimento, como debateremos adiante, como inimigos que deveriam ser capturados e neutralizados. Todavia, se operou na forma como essa população concebia o Movimento, como também na forma como a população agiu em relação aos insurgentes. O auxílio na captura dos membros de Movimento e o corredor de escarro, ambos os episódios anteriormente narrados neste trabalho, evidenciam que a narrativa da mídia se legitimou socialmente e, sendo assim, gerou práticas sociais repressivas.

Nesse sentido, percebe-se que a mídia, alocada na sociedade civil, operando na dimensão da construção de consenso, produziu efeitos na dimensão da coerção. A narrativa midiática influenciou e legitimou práticas sociais repressivas de "punição" aos insurgentes que, ao mesmo tempo, já estava atrelada à consolidação de um ambiente político propício à consolidação da tortura como política de Estado, tendo em vista que, após presos, todos os insurgentes foram duramente reprimidos e torturados. Logo, a mídia não operou apenas na dimensão do consenso, mas produziu efeitos claros na dimensão da coerção, tanto como prática social, quanto como política de Estado.

Diante disso, a concepção de Bianchi (2008) acerca da relação de unidadedistinção entre sociedade política e civil pode ser visualizada com maior clareza quando

14 Para tal problematização deve-se levar em consideração o contexto histórico no qual a produção e circulação de conteúdos midiáticos estava inserida. A censura, ainda que apenas posteriormente institucionalizada, já operava nos meios de comunicação. Além disto, deve-se compreender a relação dos grupos midiáticos frente à ascensão dos militares ao poder. Porém, parte-se do conhecimento deste debate como pressuposto, tendo em vista a impossibilidade de se retomar uma questão tão extenso em um espaço tão restrito. Para a compreensão destas questões sugere-se: MOTTA, 2013. 
se analisa de forma pormenorizada o papel da mídia na construção de consenso em relação ao Movimento de Três Passos, fortalecendo a necessidade de uma análise de unidade entre sociedade civil e sociedade política e, consequentemente, de consenso e coerção.

A experiência histórica de Três Passos, à luz das categorias analíticas de Gramsci, nos permite refletir acerca do uso dos conceitos de sociedade civil e sociedade política e, consequentemente, de consenso e coerção, enquanto categorias separadas na formulação metodológica de uma análise social. No entanto, deve-se manter cautela no momento de se pensar a totalidade do agenciamento entre coerção e consenso na realidade prática da construção de hegemonia, não permitindo que a distinção analítica estática e bidimensional seja transportada à análise concreta da realidade em questão.

Os aparelhos privados de hegemonia, alocados na sociedade civil, refletem interesses de classe e operam por meios de elementos da superestrutura na produção e reprodução da ideologia do sistema de produção capitalista. Dessa forma, o que se busca demonstrar é a operação da mídia no agenciamento da legitimação da coerção, tanto na legitimação do uso da coerção por parte da sociedade política, na repressão e na administração da justiça em relação aos insurgentes, assim como a legitimação de práticas sociais repressivas por parte da própria infraestrutura, vide apoio dos camponeses a captura dos insurgentes e a formação de corredores de escarro objetivando a humilhação pública dos membros do Movimento.

\section{$5 \quad$ Reflexões acerca do consenso em Três Passos}

Outra pergunta surge a partir da análise proposta: pode-se afirmar que a legitimação social de uma narrativa específica acerca do Movimento de Três Passos configura-se como a construção de consenso? O contexto histórico no qual o referido Movimento está inserido nos leva a indagar que forma de consenso buscou-se construir em relação aos insurgentes e, de mesmo modo, se houve realmente construção de hegemonia, isto é, agenciamento de coerção e consenso, ou se o que realmente existiu em Três Passos foi dominação sem hegemonia. 
Quando se propõe a análise do contexto brasileiro da ditadura militar, a coerção do Estado é evidente. A forma como o poder foi tomado pelos militares e as tentativas de legitimar a "revolução" por meio de atos institucionais, bem como a censura, a tortura, a perseguição a jornalistas, opositores políticos, artistas, sindicalistas, intelectuais, etc. são demonstrações claras de como o regime militar empregou a coerção como forma de manutenção da dominação.

Por conseguinte, para dar continuidade à discussão, entende-se que a coerção foi um mecanismo amplamente utilizado pelos militares na articulação da dominação. Entretanto, busca-se aqui problematizar a articulação de consenso nesse processo político. É possível identificar a influência da narrativa midiática nas ações de uma parcela, expressiva ou não, da população em relação ao Movimento de Três Passos. Não há como negar, historicamente, que os militares contaram com a ajuda de produtores rurais para localizar e capturar os insurgentes. As fontes históricas apresentadas na primeira parte desse trabalho também mostram práticas sociais repressivas de uma parcela da sociedade. Desse modo, pode-se afirmar que sim, a narrativa midiática influenciou a concepção da população em relação ao Movimento insurgente. Mas, podese enquadrar essa influência na concepção gramsciana de consenso?

O consenso, assim como o próprio conceito de hegemonia, não pode ser compreendido como uma ideologia monolítica que se instaura em dado momento histórico. Não se pode desconsiderar a capacidade dos agentes sociais de compreenderem as formas de dominação nas quais estão inseridos. O consenso, portanto, não se configura como algo dado, mas sim como uma disputa contínua.

A disputa pelo consenso presente nessa experiência de Movimento armado perpassa questões que originam e configuram o próprio contexto histórico no qual o Movimento se insere, a saber, a disputa por hegemonia entre Estados Unidos e União Soviética. A narrativa midiática influenciou a população -ou uma parcela dela- das regiões de fronteira do sul do país, por onde o Movimento passou, sobre a condenação e subjugação daqueles e daquelas que enfrentassem a ordem social e política instituída. O consenso se constituiu no âmbito do fortalecimento da ideia da necessidade de manutenção de uma determinada perspectiva material, política e social de compreender o mundo, na qual imperou a repulsa ao comunismo e a ampla adesão ao capitalismo. 
Deste modo, a narrativa midiática acerca do Movimento logra construir consenso no âmbito de legitimação de uma ordem política que buscava se consolidar por meio da ascensão dos militares ao poder, a saber, a hegemonia estadunidense na América Latina como um todo e, por consequência, a consolidação hegemônica do capitalismo como modelo social e político. Nesse paradigma, ao imperar uma perspectiva específica sobre o Movimento, o Estado logrou articular consenso, por meio de aparelhos privados de hegemonia, em relação à legitimidade e autenticidade de uma ordem social e política que buscava consolidar-se e que, no Brasil, encontrou grande expressão e suporte com a ascensão dos militares ao poder.

Entretanto, não há como afirmar a construção desse consenso apenas durante as atividades do Movimento. O início desse processo é anterior a esse e, de mesmo modo, o fim do Movimento não significa o término do processo de articulação da hegemonia. Durante as atividades do Movimento, as disputas pelo consenso são claras. Os insurgentes contaram com grande apoio de partidos políticos que ainda estavam em atividade em território nacional, com o auxílio de camponeses, líderes sindicais e até prefeitos municipais ${ }^{15}$.

O conceito de opinião pública colabora na reflexão da questão referente ao agenciamento ou não de consenso. Gramsci, afirma que:

\begin{abstract}
A opinião pública como hoje se entende nasceu às vésperas da queda dos Estados absolutistas, isto é, no período de luta da nova classe burguesa pela hegemonia política e pela conquista do poder. A opinião pública é o conteúdo político da vontade política pública, que poderia ser discordante: por isso, existe luta pelo monopólio dos órgãos de opinião pública- jornais, partidos, parlamento -, de modo que uma só força modele a opinião e, portanto, a vontade política nacional, desagregando os que discordam numa nuvem de poeira individual e inorgânica (GRAMSCI, 200o, p. 265).
\end{abstract}

Em vista disso, compreender a censura instituída pelo regime militar dentro da chave interpretativa da "luta pelo monopólio dos órgãos de opinião pública" (GRAMSCI, 2000, p. 265) nos permite compreender a mídia como um aparelho privado de hegemonia fundamental na articulação de opinião pública, como aparelho articulador

${ }^{15} \mathrm{O}$ Diário de Jefferson Cardim é uma fonte primária fundamental para analisar e compreender os diversos apoios e suportes estruturais e logísticos que o Movimento teve ao longo do processo de planejamento e execução da Operação de Três Passos. 
da vontade política. Portanto, a emissão de um discurso específico acerca do Movimento e a busca pela "elucidação dos fatos" nos permite compreender a narrativa midiática não como articuladora de consenso, mas sim como agenciadora de opinião pública. Estava pautada no discurso midiático a impressão de uma direção moral da sociedade, referente a não insurgência e, com isso, a aceitação de uma autoridade política específica que, por sua vez, pautava uma direção intelectual e moral da sociedade.

Assim, compreende-se a legitimação de um discurso específico acerca do Movimento não como articulação de consenso, mas sim de formação de opinião pública. Ora, a opinião pública, operando por meio da imprensa, caracteriza-se como a cristalização do consenso e está a ele relacionado. Nesse sentido, a opinião pública formada a partir da narrativa midiática em relação ao Movimento de Três Passos buscava fortalecer e legitimar socialmente o regime militar e a percepção de sociedade incorporado por esse regime político. Pode-se afirmar ainda que a mídia, portanto, agenciou a construção de uma opinião pública específica objetivando a formação de uma moralidade coletiva.

Nesse contexto, consolidou-se, no que diz respeito ao Movimento de Três Passos, a dominação sem hegemonia, imperou a coerção no processo de supressão do Movimento, atrelado a formação de uma opinião pública que projetava a fundamentação do processo de construção de um consenso específico. Contudo, ao fim do processo histórico da ditadura militar, logrou-se agenciar coerção e consenso. Ou seja, compreendida como uma experiência histórica micro dentro do contexto nacional e internacional no qual está inserida, a experiência armada de Três Passos nos permite identificar a formação de uma opinião pública específica, atrelada à dominação pela coerção. Ademais, a partir disso, também nos possibilita projetar, à luz do desenvolvimento histórico da ditadura militar brasileira, bem como do processo de redemocratização, a cristalização de consenso, por meio da formulação de opinião pública, além de possibilitar a compreensão o contexto macro da ditadura militar brasileira a partir do conceito de construção de hegemonia em relação à consolidação do capitalismo como ordem política e social.

Deste modo, a formação de opinião pública em relação ao Movimento de Três Passos não se reduz a forma como a mídia logrou influenciar a concepção de uma parcela 
da população em relação ao Movimento, mas sim, em âmbito micro, como os aparelhos privados de hegemonia do Estado, por meio da construção de uma opinião pública, colaboraram na legitimação e na consolidação de uma perspectiva específica de sociedade, isto é, de consenso. Essa relação de unidade entre coerção e consenso se vislumbra, com certa nitidez, na parcela da população que agiu diretamente a fim de reprimir os insurgentes, como narrado anteriormente. Todavia, dentre aqueles/as que não agiram, poderia imperar ou não a concordância com as práticas repressivas do Estado ou com a insurgência do Movimento, mas não há como precisar tal afirmação. Cabe salientar, porém, que essa parcela se manteve passiva, o que também possibilita o pensar sobre a imposição da hegemonia estatal a partir da passividade da ação.

\section{O processo de hegemonia e a redemocratização}

O processo de redemocratização e o pacto conciliatório entre civis e militares, com o término do regime militar, possuíam uma pauta central: a retomada da democracia como regime político nacional, por meio de eleições diretas, gerais e livres. Consolidou-se progressivamente, a partir daquele momento, uma agenda política específica, de disputa organizada dentro de um novo regime político. Levando em consideração o contexto político do momento compreende-se a euforia com o reestabelecimento de uma democracia a nível nacional e não há intenção alguma de questionar o valor dessa conquista para a política brasileira.

Busca-se, no entanto, problematizar, em certa medida, como o processo de redemocratização pode ser compreendido dentro da chave analítica do processo de construção de hegemonia e como a mídia colaborou, enquanto aparelho privado de hegemonia, na construção de consenso em relação à transição democrática. Busca-se ainda, problematizar se a formação da opinião pública que a mídia buscava articular em Três Passos pode ser compreendida como uma parte articuladora desse consenso macro articulado na redemocratização. Em outras palavras, indaga-se: é possível analisar a formação de uma opinião pública contrária à insurgência e à contraposição a ordem política instaurada com a ditadura com o consenso em relação ao estabelecimento da democracia como regime político? 
Progressivamente, com a consolidação das eleições diretas, a agenda política dos partidos de esquerda brasileira voltou-se à disputa eleitoral pelo governo. Deixou-se de lado, progressivamente, a disputa por outro projeto de Estado, de economia e de sociedade. Acatou-se, por fim, a democracia como regime político inquestionável, dados os dolorosos processos enfrentados durante o autoritarismo militar. Com a retomada da democracia, uma parte expressiva da esquerda brasileira despiu-se da disputa política antagônica à hegemonia capitalista. Acataram-se bases e fundamentos sociais capitalistas em troca da manutenção da garantia de direitos humanos e políticos.

Diante desse panorama, o mesmo sistema de articulação de hegemonia em relação a uma ordem social específica que buscava consolidar-se com a ascensão dos militares precisava deixá-los [os militares] para trás para seguir vigente. Deste modo, a redemocratização pode ser compreendida como uma nova fase de dominação e, consequentemente, de articulação de hegemonia.

A articulação de uma classe específica e dirigente no centro do Estado, que durante o regime militar atrelava- $\mathrm{se}^{16}$ com o Exército e com capital financeiro internacional, agora precisava rearticular-se para seguir disputando e se unificando, ainda que por vezes de forma desarmônica, no poder do Estado. Não obstante, ainda que rearticulado, o Estado manteve seu caráter de unificação e articulação das classes dirigentes.

Contudo, como destaca Roseberry (1994), o processo de construção de hegemonia, por ser inerente à disputa e a luta política, é conflituoso e, sendo assim, pode, por vezes, ser frágil. Desse modo, a democratização nacional, mantém-se, de modo similar, fragilizada. A sua manutenção e continuidade depende da manutenção e continuidade da hegemonia capitalista.

O processo de redemocratização pode ser posto em análise como uma continuidade do processo de articulação de consenso e coerção, presentes na disputa política brasileira, desde o contexto pré-golpe de 1964. De mesmo modo, é possível visualizar a forma como Estado, por meio dos aparelhos privados de hegemonia, buscou articulação consenso e coerção em relação as bases sociais capitalistas, tanto em nível

\footnotetext{
${ }^{16}$ Para aprofundar os debates acerca das disputas pelo poder do Estado durante o regime militar ver: Boito, 2014 .
} 
micro, a partir da experiência armada de Três Passos, quanto em nível macro, no processo de redemocratização. Pode-se, assim, traçar paralelos acerca da articulação de hegemonia entre ambas as experiências históricas.

\section{$7 \quad$ Considerações finais}

Em suma, o que se buscou problematizar foi a possibilidade de pensar o Movimento de Três Passos e a articulação de consenso e coerção presentes nessa experiência histórica de luta armada, em âmbito micro, como mecanismo para compreender e analisar o processo de construção de hegemonia em nível macro. Os aparelhos privados de hegemonia sendo, no caso dessa pesquisa, a mídia, logrou articular um consenso tácito, tanto no caso de Três Passos, por meio da formação de uma opinião pública que legitimava a violência contra aquelas e aqueles que subvertessem a ordem política vigente, quanto no contexto da redemocratização, acerca da necessidade da consolidação, no primeiro caso, e da manutenção, no segundo caso, da hegemonia capitalista no cenário social, político e econômico do Brasil.

De mesmo modo, buscou-se refletir acerca da existência ou não de limites ou fronteiras entre a sociedade civil e a sociedade política e, consequentemente, do consenso e da coerção. Dessa forma, tratou-se de identificar elementos históricos que nos permitam visualizar como a mídia, enquanto aparelho privado de hegemonia, atuando na dimensão da articulação de consenso, operou também na esfera da coerção, legitimando socialmente práticas sociais repressivas e propiciando o estabelecimento de um ambiente político favorável ao emprego da tortura como política de Estado.

Sendo assim, essa proposta analítica nos permite revisitar pontos centrais da obra de Gramsci e pensar o presente a partir do passado. Em que medida a redemocratização pode ser compreendida como continuidade do processo de articulação de hegemonia? E, caso aceitas tais considerações teóricas acerca da possibilidade desta análise, como pensar a continuidade da construção de hegemonia no presente? Tais reflexões devem ser pensadas de forma pormenorizada em futuros trabalhos. 


\section{Referências}

BIANCHI, A. O Laboratório de Gramsci. Alameda Editorial, UNICAMP, 2008.

BOITO, A. Entrevista: Os Civis Vestiram a Farda?. Jornal da UNICAMP. Campinas- SP, 2014 .

CADEMARTORI, L. M. D. A operação três passos: A história, o Direito e o Político. Dissertação (Pós-graduação em Direito)- Mestrado em Ciências Humanas, Universidade Federal de Santa Catarina, Florianópolis, 1993.

FLICK, U. Introdução à Pesquisa Qualitativa. Editora Artmed, Porto Alegre, 2009.

GASPARI, E. A ditadura envergonhada: Edição com fotos, 2002.

GRAMSCI, Antonio. Cartas do cárcere. Rio de Janeiro: Civilização Brasileira, 2005.

GRAMSCI, A. Cadernos do Cárcere volume 3: Maquiavel. Notas sobre o Estado e a Política. Editora Civilização Brasileira, 7. Ed, Rio de Janeiro, 2016.

MACIEL, D. Democratização e manutenção da ordem na transição da ditadura militar à Nova República (1975-1985). Dissertação (Pós-graduação em História)- Mestrado em História das Sociedades Agrárias, Universidade Federal de Goiás, Goiânia, 1999.

MOTTA, S. P. R. A ditadura nas representações verbais e visuais da grande imprensa: 1964-1969. Revista TOPOI, v.14, n. 26, 2013.

PALMAR, A. Onde foi que vocês enterraram nossos mortos? Travessa de Editores, $4^{\text {}}$ Ed. Curitiba, 2012.

REY, M. T. El Estado Ampliando en el Pensamiento Gramsciano. IN: La noción Gramsciana de hegemonia en el convulsionado fin de siglo, Universidad Nacional de San Luis, 2010.

ROSEBERRY, W. Hegemonia y lenguaje contencioso. IN: En: Joseph Gilbert y Daniel Nugent, Everyday Forms of State Formation. Revolution and the Negotiation of Rule in Modern Mexico. Durham and London, Duke University Press. 1994. 